\title{
Chinese Atheism in the Mémoires de Trévoux: a Cultural Project against the Existence of a Perfect Atheism
}

\author{
Michela Catto \\ University of Modena and Reggio Emilia \\ michelacatto@gmail.com
}

\begin{abstract}
In the first decades of the eighteenth century, the Society of Jesus was busy changing its interpretation of the Chinese world and denying the possible existence of a society of atheists. To safeguard the Chinese mission, the Jesuit Antonio Provana claimed that European cultural models could not be used in order to interpret China, and that the voices and purported beliefs of the Chinese should be reported on their own terms. The same refusal to interpret Chinese culture through the interpretative schemes that European cultures had inherited (largely from the ancient Greeks or Romans) also filled the pages of the Jesuit journal Mémoires de Trévoux between 1701 and 1719, the period analyzed in this contribution. My article in this special issue argues that, due to the extreme rhetorical caution necessary to the Jesuits in France during the third phase (1700) of the Chinese rites controversy, the Mémoires de Trévoux pursued a cultural policy intended to deny the existence of any atheism whether in a single individual or in a whole nation. This departure from a Eurocentric perspective, as well as the denial of atheism in any form, became themes that forcefully reappeared during the Enlightenment.
\end{abstract}

\section{Keywords}

China - atheism - Enlightenment - Chinese Rites Controversy - libertinism 
In 1693, the apostolic vicar of Fujian Charles Maigrot (1652-1730), ${ }^{1}$ a member of the Foreign Missions of Paris, issued a condemnation of the method of evangelizing used by the Society of Jesus in China. In his Mandatum seu Edictum (Mandated edict) Maigrot banned the Jesuits' whole system of accommodatio. Not only did Maigrot forbid the tactical accommodation of Chinese rites, a question that had already been long debated among the religious orders, he also condemned any attempt to bring Christian doctrine and Chinese philosophy closer, as well as any cultural "conformity" between Christian and Chinese morality so exalted by the early Jesuits in China since the writings of Matteo Ricci (1552-1610). In the process of arguing for such sweeping condemnations, the apostolic vicar of Fujian defined the Chinese as atheists, and ascribed the division or classification of the Chinese Confucians into atheists and deists to the intervention by the Society of Jesus itself. ${ }^{2}$ The condemnation of Confucian philosophy, and of its most ancient texts, thus revived the European debate about the existence of peoples who had never known Christianity, a debate driven in large measure by the stories of savage and civilized peoples told by travellers and missionaries who had questioned the biblical chronologies and, with them, the truthfulness of sacred history as a universal story.

The existence of an atheism, positive or negative atheism (that is someone who believes that God does not exist and someone without a belief in $\operatorname{God}^{3}$ ) and of a morality preceding the Christian revelation was sometimes the tacit subject of a journal founded in France by the Society of Jesus: the Mémoires de Trévoux (Memoirs of Trévoux). This famous monthly published some two thousand pages a year of reviews, in addition to large sections of printed works published in Christian Europe. As it gave space to, or attempted to silence, the books published during the early decades of the eighteenth century, the

1 Claudia von Collani, "Le Père Joachim Bouvet et le mandement du vicaire apostolique Charles Maigrot," in Actes du Ve Colloque international de Sinologie de Chantilly, 15-18 septembre 1986: Succès et échecs de la rencontre Chine et Occident du XVI ${ }^{e}$ au $X X^{e}$ siècle (San Francisco: The Ricci Institute for Chinese - Western Cultural History - University of San Francisco, 1993), 77-100, and von Collani, "Charles Maigrot's Role in the Chinese Rites Controversy," in The Chinese Rites Controversy: Its History and Meaning, ed. David E. Mungello (Nettetal: Steyler Verlag, 1994), 149-83.

2 This definition, a last attempt to counter permanently the Jesuit theory, was coined by Charles Maigrot, the apostolic vicar of Fujian, in Historia cultus Sinensium seu varia scripta (Cologne: n.p., 1700), 318.

3 See also Michael Martin, "General Introduction," in The Cambridge Companion to Atheism, ed. Michael Martin (Cambridge: Cambridge University Press, 2007), 1-7 and Gianluca Mori, L'ateismo dei moderni: Filosofia e negazione di Dio da Spinoza a d'Holbach (Rome: Carocci, 2016), 195-240. 
Mémoires in effect waged a cultural war ${ }^{4}$ in as much as it did not deal directly with the Chinese rites controversy but supported the point of view of the Society of Jesus in China.

In the present essay, the Society of Jesus is shown to be expressing a position of cultural cosmopolitanism that was in the process of becoming increasingly pervasive in early eighteenth-century culture; this form of cultural cosmopolitanism on the one hand recognized the authority and autonomy of other civilizations, while on the other hand rejecting — not always sincerely and consistently - the application of a more Eurocentric vision in favor of the positive role played by all religions in the world. Obviously, in the case of Society of Jesus (an order instituted with the principal aim of dealing especially with the defence and propagation of the faith), and of missionaries in general (animated, as they were, by the desire to spread the Gospel throughout the world), the primary goal was to preserve the mission, and to universally proclaim the salvation announced by Catholic revelation. Yet, as this contribution reveals, the writings of the Jesuit Giuseppe Antonio Provana (1662-1720), who was to defend the practice of Chinese rites on the Chinese emperor's behalf in Rome in 1709, furnished an explicit statement calling for European religious authorities to duly consider the Chinese worldview on its own terms in order to properly contextualize and interpret the experience and needs of Jesuits missionaries on the ground in China. Second, contributors to the Mémoires de Trévoux followed a path similar to that of Provana. In reviews of, and offhand comments about, the most important and relevant books published in Europe, editors and contributors to the Mémoires de Trévoux elaborated a precise strategy aimed at dispelling even the possibility that atheism might exist, whether in a single individual, a group, a population, or an entire society such as that of the Chinese Empire.

The Society of Jesus's information, tales, and opinions about the people of the world provided food for thought to many varieties of European Enlightenment, as by studies Virgile Pinot, Sergio Landucci, Sergio Zoli, Giuliano Gliozzi,

4 On the role of French Jesuits in eighteenth-century culture see Jeffrey D. Burson, "Distinctive Contours of Jesuit Enlightenment in France," in Exploring Jesuit Distinctiveness: Interdisciplinary Perspectives on Ways of Proceeding within the Society of Jesus, ed. Robert A. Maryks (Leiden: Brill, 2016), 212-34; Burson, "Between Power and Enlightenment: The Cultural and Intellectual Context for the Jesuit Suppression in France," in The Jesuit Expulsion: Causes, Events, and Consequences, ed. Jeffrey D. Burson and Jonathan Wright (Cambridge: Cambridge University Press, 2015), 40-64; and Burson, The Rise and Fall of Theological Enlightenment: Jean-Martin de Prades and Ideological Polarization in Eighteenth-Century France (South Bend, IN: University of Notre Dame Press, 2010). 
and works far too numerous to mention have shown. ${ }^{5}$ The Society of Jesus found itself selecting the works that they believed deserved credit and promotion among European intellectuals, yet, it could not ignore the often dubiously orthodox studies that so often fed on the Jesuits' own descriptions of far away lands. Descriptions of Confucianism as the atheist doctrine that ruled China despite the fact that China, itself, was a country possessing a generally good government and excellent customs effectively revived in Europe the never truly resolved debate about political atheism and the existence of a link between morals and religion. The questioning of prevailing orthodox opinion, which had until then technically excluded the presence of salutary morality in within a society lacking religion led the Society of Jesus to much greater caution in defining Confucian ethics as atheist. In this way also, this article suggests that the Society was ironically taking part in Enlightenment culture, alongside those philosophes (for instance Voltaire) of a deist persuasion who criticized and opposed Christianity, but could not, themselves, accept the existence of a society of atheists.

\section{Antonio Provana: the Impossible Existence of True Atheists in China}

In 1709, the Jesuit Antonio Provana ${ }^{6}$ arrived in Rome leading an embassy organized by Emperor Kangxi (r.1661-1722). ${ }^{7}$ The emperor of China had provided Provana with letters patent and a series of documents attesting to the exclusively civil and political function of the Chinese rites when he sent him to Rome for the purpose of settling the matter of Chinese rites in the presence of the pope himself. The Chinese rites controversy, rekindled by Charles Maigrot's decision, had in fact continued with the arrival in Beijing in 1705 of the legate

5 The scholarship concerning atheism and the Enlightenment is vast. See especially, Eugenio Lecaldano, Senza Dio: Storie di atei e ateismo (Bologna: il Mulino, 2015) and Emanuela Scribano, L'esistenza di Dio: Storia della prova ontologica da Descartes a Kant (Rome: Laterza, 1994).

6 Eugenio Menegon, "Provana Antonio," in Dizionario biografico degli italiani (Rome: Istituto dell'Enciclopedia Italiana, 2016), 75:505-8, and John W. Witek, "Provana Antonio," in $D H C J$, 4:3246-47.

7 In general, about the Jesuits sent to Europe by Kangxi, see John W. Witek S.J., "Sent to Lisbon, Paris and Rome: Jesuit Envoys of the Kangxi Emperor," in La missione cattolica in Cina tra $i$ secoli XVIII-XIX: Matteo Ripa e il Collegio dei cinesi; Atti del Colloquio internazionale, Napoli, 11-12 febbraio 1997, ed. Michele Fatica and Francesco D'Arelli (Naples: Istituto Universitario Orientale Collana “Matteo Ripa," 1999), 317-40. 
a latere, commissioner, and general visitor of all the missions of the Far East, Charles Thomas Maillard de Tournon, patriarch of Antioch (1668-1710). ${ }^{8}$ His attitude towards the Chinese religion and to the Kangxi emperor in particular, as well as his mandate of February 1707 prohibiting the participation of Chinese Christian converts at the traditional rites honoring Confucius ( $c .55^{-}$ 479 BCE) and their ancestors, had led to a very difficult moment for the China mission.

Provana's positions were a clear expression of Jesuit politics in China concerning the Chinese rites. These positions Provana articulated in five memoirs he presented to Pope Clement XI (r.1700-21), together with related Chinese imperial documents he conveyed to Europe; these memoirs and documents he published in Atti imperiali autentici di varj trattati passati nella Regia corte di Pekino tra l'Imperatore della Cina e M. Patriarca Antiocheno al presente Sign. Cardinale di Tournon negli anni 1705 e 1706 (Imperial acts authenticated from various exchanges at the royal court of Beijing between the emperor of China and Cardinal de Tournon, patriarch of Antioch, in the years of 1705 and 1706).9 This work animated discussions and inspired the further publication of controversial works (some favoring the Jesuits' position, and some favoring Tournon's condemnation); ${ }^{10}$ these works then became the main sources examined by the Congregation of the Inquisition until the final prohibition of the Chinese rites in $1742 .{ }^{11}$ Provana's reflections brought into focus two partially new themes. Within the usual dialectical modalities that had characterized the debate among religious orders (in which insults mixed with theological issues),

8 See the detailed reconstruction in Giacomo Di Fiore, La legazione Mezzabarba in Cina (1720-21) (Naples: Istituto Universitario Orientale, 1989) and António Vasconcelos de Saldanha, De Kangxi para o Papa, pela via de Portugal: Documentos relativos à intervenção de Portugal e da Companhia de Jesus na questão dos Ritos Chineses e nas relações entre o Imperador Kangxi e a Santa Sé, 3 vols. (Lisbon: Instituto Português do Oriente, 2003).

$9 \quad$ Published with the title Atti imperiali autentici di varj trattati passati nella Regia corte di Pekino tra l'Imperatore della Cina e M. Patriarca Antiocheno al presente Sign: Cardinale di Tournon negli anni 1705 e 1706.

10 Recently republished in Kilian Stumpf, S.J., The Acta Pekinensia or Historical Records of the Maillard de Tournon Legation, ed. Paul Rule and Claudia von Collani (Rome: Institutum Historicum Societatis Iesu, 2015).

11 Michela Catto, "Superstizione, monoteismo e unità della Chiesa: Benedetto XIV e la condanna dei riti cinesi (1742)," in Storia, medicina e diritto nei trattati di Prospero LambertiniBenedetto XIV, ed. Maria Teresa Fattori (Bologna: Edizioni di Storia e Letteratura, 2013), 97-108 and Catto, "La controversia sul culto a Confucio ai tempi di Benedetto XIV e la 'scomparsa' dell'ateismo," in I gesuiti e i papi, ed. Catto and Claudio Ferlan (Bologna: il Mulino, 2016), 53-76. 
the reflections of Provana drew attention to the question of whether the Chinese scholar gentry were truly classifiable as atheists while at the same time addressing the need to give the Chinese point of view due consideration in any assessment of the nature of their Confucian rites and doctrine.

Provana's reflections urged European scholars to use caution when evaluating the language of ancient Chinese texts and artefacts, especially with regard to the most ancient of Chinese "hieroglyphs" in which obscure meanings were often hidden. Yet in pursuing this train of thought, Provana's argument raised the thorny issue of authority. In fact, Provana was accused of having compared the pontifical decrees to the imperial decree that Kangxi had given him in order to explain the Chinese rituals, and in so doing, of having tacitly conferred greater prestige on the latter and questioned the supremacy of papal authority. Luigi Vincenzo Mamiani della Rovere (1652-1730), the author of two interventions in Provana's defence, not only insisted that Provana's opponents show linguistic proofs of his bad faith (his "satirical" intent against the Jesuits), he also insisted on the aptness of Provana's method..$^{12}$ In other words, della Rovere believed that Provana had been right to say that in order to judge the rites, the ceremonies, and beliefs of a faraway world, even the pope must first consult people "well versed in the customs of that remote country" (namely European religious orders with a deep experience of Chinese culture), and the emperor himself "who state[d] that in said ceremonies conforming to their institution, there is no belief in assisting spirits, no prayers etc."13 Facts had to be distinguished from laws, and in this regard, "every monarch or legislator can be a competent judge of the laws and customs of his empire without affecting the infallible judgment that the Church can give in the matter of those same laws and customs, when declaring them either licit or illicit."14 In order to avoid improper interpretations, the need for different cultural categories was emphasized, and implicitly, Provana's documents suggested that many errors had

12 These are the thirty-two pages of Osservazioni sopra la risposta fatta dal Procuratore del Signor Cardinal di Turnon a cinque Memoriali del P. Provana Procuratore de' Missionarij della Cina della Compagnia di Gesù ([Rome]: n.p., 1709) and of La verità e l'innocenza de' Missionarij della Compagnia (sine notis) both replying to Giovanni Giacomo Fatinelli's accusations against Provana in Apologia delle risposte date [...] alli cinque memoriali del P. Provana. Contro le osservazionifatte sopra di esse (N.p.: n.p., 1710).

13 [L. V. Mamiani della Rovere], Osservazioni, 20.

14 [L. V. Mamiani della Rovere], Osservazioni, 21. On the "point of fact" see David Porter's interesting interpretations "China and the Critique of Religious Fanaticism in EighteenthCentury France," in Les Lumières européennes dans leurs relations avec les autres grandes cultures et religions, ed. Florence Lotterie and Darrin M. McMahon (Paris: Honoré Champion, 2002), 61-79, here 68-73. 
already been made because of the exclusive use of the church's own cultural, philosophical, and theological systems in the understanding of the Chinese worldview. But the issue of the emperor's authority in providing interpretative material about the rituals practiced in his own empire was seen by opponents of the missionaries as a concession, a diminution of papal power made worse by the fact that the emperor was thought to be an atheist emperor of a nonChristian people. This objection again raised the core issue underscored by critics of Provana's mission: could the emperor of China be a true atheist and still rule China in accordance with excellent moral principles? Moreover, as an atheist, could he be judged honest and trustworthy?

In his Memoriali, Provana polemically asked how Chinese atheism could be consistent with their rites, "with sacrifices that, as Opponents' say, are offered to Heaven and Earth, and to other Spirits or to the other Literati, with the prayers they address[ed] to Confucius and [to] the Deceased with the belief in assisting Spirits, and in hopes of happiness," and remarked on the logical absurdity. ${ }^{15}$ Provana noted the logical absurdity of believing that such ritual meanings and the desires animating those practices could be consistent with a "perfect atheism." This observation echoed similar debates underway among European theologians and scholars on the existence of atheism, a doctrine that could deliberately deny the existence of God without corrupting human morality. In the view of the Society of Jesus, the atheism of the Chinese- that of the Confucian mandarins-had arisen from the corruption of an ancient monotheism, but in a way that had led to irreproachable morality, and the perfect precondition for Chinese scholar gentry to deny the presence of idolatry and superstition because they believed that no God was better than fake and inconsistent gods, and indifference is better than reason inhibited by the belief in gods capable of generating evil. ${ }^{16}$

The Jesuit Provana was no less polemical in his defence of the Chinese name of God forbidden by the new decrees. In fact, Provana emphasized the contradiction inherent in those who supported the opinion that "all Chinese scholars, and their leader, were perfect atheists" and therefore lacking a word "in their Idiom" to express "the meaning of the primal intelligence that is God." If for centuries the Chinese had no word to express God, they would have been unaware of the "Intelligence of a Supreme Deity against the Doctrine of

15 Archivio Segreto Vaticano, Fondo Albani, vol. 237, Congregationes Sancti Officii super rebus Sinensibus (8 augusti-4 octobris 1709 ), cc. $233^{\mathrm{r}-\mathrm{v}}$.

16 On the Chinese's atheism see Michela Catto, "Atheism: A Word Travelling to and for between Europe and China," in The Rites Controversies in the Early Modern World, ed. PierreAntoine Fabre and Ines G. Županov (Leiden: Brill, 2018), 68-88. 
St. Paul followed by all theologians." "To defend a perfect atheism in all the Chinese and in their Leader" by claiming "that they have no voice to express the knowledge of God" was in effect to deny the validity of Pauline theology (Romans 1:18-20). ${ }^{17}$

As described by the Society of Jesus, China was a well-governed and morally upright society despite the coexistence of religions within its borders and the instrumental use of such religious diversity by the imperial state for political ends. China was thus rhetorically constructed as a successful model that would be welcomed by the European Enlightenment even as it would continue to raise many questions for Christianity's defenders, especially and ironically for the Jesuits, themselves, who had effectively built the collective imagination of Confucian society as understood by Europeans. ${ }^{18}$ The Jesuits had done so by extolling China's virtues, tracing them back to an ancient monotheism corrupted into atheism, but one still less despicable than idolatry and superstition. In order to safeguard their mission and their theology, they now had to defend the position that Chinese atheism was not true atheism because, if China were the model of a virtuous society, it could not be atheist, and moreover, a society of atheists could not exist. Making matters worse by the dawn of the eighteenth century was the fact that the survival of the Chinese mission was at stake, and above all, Jesuit control over the consequences that its own narratives and interpretations of Chinese culture had on European culture and morality. Neutralizing the religiosity contained in Confucianism had proven to be an expedient with serious consequences for the European world. ${ }^{19}$ In short, the Chinese rites controversy compelled the Jesuits to desacralize Chinese Confucian rites and defend the Qing dynasty's own interpretation of these

17 Provana's argument was reported in those same words by Mamiani but resolved in favor of the position that the Chinese scholars were purely, truly, and perfectly atheist in the pages of the Apologia delle risposte date dal procuratore dell'eminentissimo Signor Cardinale di Tournon alli cinque memoriali del P. Provana contro le Osservazioni fatte sopra di esse da un autore anonimo [Apology of the answers given by the procurator of the very eminent Cardinal of Tournon to the five memoirs of Fr. Provana against the Observations made against them by an anonymous author] (1710) by Giovanni Giacomo Fatinelli. Fatinelli was the editor, alongisde Charles Maigrot, Nicolas Charmot, Giovan Francesco Nicolai, Giovanni Donato Mezzafede, and Ignazio Giampé, of Ex illa die (March 19, 1715). On this point, see Michela Catto, "Nicolai Giovan Francesco," in Dizionario biografico degli italiani (Rome: Istituto dell'Enciclopedia Italiana, 2013), 78:475-77, here 476.

18 See Jonathan Israel, "La querelle sur Confucius dans les Lumières européennes (16701730)," Rue Descartes 82, no. 2 (2014): 64-83.

19 See Guy G. Stroumsa's considerations, A New Science: The Discovery of Religion in the Age of Reason (Cambridge, MA: Harvard University Press, 2010), 145-49. 
rites against the Papal Curia, itself. Yet in so doing, the Jesuits not only further endangered the security of their mission in China, and the security of their own position relative to the papacy, they further found themselves compelled to find new solutions to the question of whether China was ruled by atheists.

\section{Perfect Atheism: a Chinese Issue and a European Problem}

The Mémoires de Trévoux (or Journal de Trévoux as it is sometimes called) was founded at a particularly critical moment for the Jesuits of France and was involved in various capacities in the many controversies of the first half of the eighteenth century: from the Chinese rites to Jansenism, from Cartesianism and Malebranchism, to revolutions and scientific discoveries. The journal immediately appeared as an instrument of Jesuit culture and of its apologetics, as a means of counteracting the influence of journals and books published in the countries ruled by Protestant "heretics," particularly the Netherlands; it was therefore committed to exposing, through critical reviews, important changes in eighteenth-century ideas. ${ }^{20}$ Like all cultural journals, the Mémoires did not simply report, criticize or praise a book; it served its function for the republic of letters at its best by its choice of what deserved attention (whether positive or negative), by directing interests and guiding curiosities, and by placing itself at the center of great philosophical dispute as a sounding board for the main intellectual currents of the age, or as a strategic road block designed to prevent their success. ${ }^{21}$

The querelle of the Chinese rites had peaked in France just after the foundation of the journal. In 1700, in fact, the Sorbonne issued a decree condemning some books about China written by important Jesuits of France and of the

20 Mémoires de Trévoux, February 1712: 222; on the history of the Mémoires de Trévoux, see Alfred R. Desautels, S.J., Les Mémoires de Trévoux et le mouvement des idées au XVIII ${ }^{e}$ siècle, 1701-1734 (Rome: Institutum Historicum S.I., 1956), and Christian Albertan, "Entre foi et sciences: Les Mémoires de Trévoux et le mouvement scientifique dans les années 50," Dix-huitième siècle 34 (2002): 91-97; see also John M. Pappas, Berthier's Journal de Trévoux and the Philosophes (Geneve: Institut et Musée de Voltaire Les Délices, 1957).

21 On censorship mechanisms and the contradictory balance of censorship in the République des Lettres, see Robert Darnton, Censors at Work: How States Shaped Literature (New York: Norton, 2014); on Jesuit literary and critical practices, see more generally in Dinah Ribard, "Pratique(s) jésuite(s) de l'écrit: Le P. Tournemine, les Mémoires de Trévoux et Fénelon," Dix-septième siècle 228, no. 3 (2005): 513-26, and Gianfranco Cantelli, "Mito e storia in Leclerc, Tournemine e Fontenelle," Rivista critica di storia della filosofia 3 (1972): 269-86 and 4 (1972): 385-400. 
Chinese mission including Nouveaux mémoires sur l'état présent de la Chine (New memoirs on the present state of China) (1696) and Lettre des cérémonies de la Chine (Letter concerning the ceremonies of China) (1700) by Louis Le Comte (1655-1728), a member of Louis XIV's (r.1643-1715) famous mission of mathematicians and the duchess of Burgundy's confessor; and Histoire de l'édit de l'empereur de la Chine en faveur de la religion chrétienne avec un éclaircissement sur les honneurs que les Chinois rendent à Confucius et aux morts (History of the edict of the emperor of China in favor of the Christian religion with a clarification on the tribute that the Chinese pay Confucius and to the dead) (1698) of Charles Le Gobien (1671-1708). More important still were the reasons for such condemnations. ${ }^{22}$ The Sorbonne's condemnation of these works struck at the core of the Jesuits' missionary methods and applied Maigrot's principles. But the condemnation also seemed to answer some of the historical, philosophical, and theological trends that had flourished since the middle of the seventeenth century, when, in order to justify the very remote antiquity of pagan cultures in his Prae-Adamitae (1655), Isaac La Peyrère (1596-1676) had assumed that men had existed before Adam. ${ }^{23}$ Prae-Adamitae had elaborated a polygenetic hypothesis that reconciled the data about other cultures, the oldest chronologies of the Chinese and the Mexicans, with the Bible. ${ }^{24}$ The Sorbonne censored (as "false," "reckless," "scandalous and wrong," "insulting to the holy Christian religion or the word of God," and "heretical") each statement the three books had advanced concerning the knowledge of a true God, the practice of sacrifice "in the most ancient Temple of the Universe." The Sorbonne also censured any reference to the presence of a morality as pure as religion, to the conformity between Christianity and Chinese doctrine, or to any statements that had benefited or attempted to refute the consensus gentium theory (the argument that universal consent as to the existence of one God had prevailed among all human cultures before their degeneration into idolatry and superstition). ${ }^{25}$

22 John W. Witek, "Le Comte, Louis-Daniel," in DHCJ, 3:2301-2.

23 Cf. Sergio Zoli, "Il preadamitismo di Isaac de la Peyrère nell'età previchiana e il libertinismo europeo del Seicento," Bollettino del Centro di Studi Vichiani 21 (1991): 66-77.

24 Giuliano Gliozzi, Adamo e il nuovo mondo: La nascita dell'antropologia come ideologia coloniale: dalle genealogie bibliche alle teorie razziali (1500-1700) (Florence: La Nuova Italia Editrice, 1977).

25 "Censure de la Sacrée Faculté de Théologie de Paris. Portée contre les Propositions extraites des Livres intitulés: Nouveau Memoires sur l'Etat present de la Chine, Histoire de l'Edit de l'Empereur de la Chine, Lettre des Ceremonies de la Chine." (n.p., 1700). On this censorship, see Virgile Pinot's still valid reflections in La Chine et la formation de l'esprit philosophique en France (1640-1740) (Paris: Librairie Orientaliste Paul Geuthner, 1932), 
An analysis of how the Jesuits of France participated in this cultural climate only further sheds light on just how little space and scant attention was paid to querelle of the Chinese rites in the pages of the Mémoires de Trévoux. From 1701 to 1719, when René Joseph Tournemine (1661-1739) edited the journal, only two reviews addressed the issue. In fact, in 1702 the journal reported on only two works that concerned the Chinese rites: the first was Discrepanze o contraddizioni intorno al fatto tra' moderni impugnatori de' riti cinesi (Discrepancies or internal contradictions to the fact among modern interlocutors over of the Chinese rites) published in Cologne in 1700 and again in 1701 by the Jesuit Baldassare Montecatini (1651-1720), professor of positive theology at the Roman College; the second was Lettere a un abate di qualità intorno alla materia di uno scritto intitolato lettera di Monsignor Luigi di Cicè nominato dalla Santa Sede al vescovado di Sabula. Ai RR Padri Gesuiti sulle idolatrie e superstizioni della Cina (Letter to an abbot of quality on the matter of a work entitled letter of His Eminence Luigi di Cicè, named by the Holy See to the archbishopric of Sabula to the reverend Jesuit fathers on the idolatries and superstitions of China), published in Cologne in 1701 - a refutation of the first work by Montecatini, and therefore opposed to the Chinese rites. ${ }^{26}$ The long review, full of casuistry aimed at denouncing, first, the contradictions in the testimony of Louis de Cicé (1648-1727), member of the Foreign Missions and apostolic vicar of Siam and Japan, and second, the unfounded accusations against the Society of Jesus, was followed in June 1702 by an equally polemical review of Réponse aux nouveaux écrits de Messieurs des Missions étrangères contre les Jésuites (Reply to the new writings of the gentlemen of the foreign missions against the Jesuits). ${ }^{27}$ In the latter, Tournemine argued that the emperor of China could hardly be mistaken about the meaning of ceremonies in use in his own country, and thus that "Christian prudence requires that when there is a need to choose between two parties, to one of which a certain wrong is attached, and to the other a wrong dubious at most, one should tolerate the wrong that is

135-56; see also Gianfranco Cantelli, Teologia e ateismo: Saggio sul pensiero filosofico e religioso di Pierre Bayle (Florence: La Nuova Italia, 1960), and his Vico e Bayle: Premesse per un confronto (Naples: Guida, 1971), especially 9-30.

26 For Tournemine's years as editor, see Jean de Viguerie, Histoire et dictionnaire du temps des Lumières, 1715-1789 (Paris: Robert Laffont, 2007), 1410-11; for reviews of the work by Baldassare Montecatini and that of his interlocutor, see Mémoires de Trévoux (March 1702): 132-57; and Riccardo García Villoslada, S.J., Storia del Collegio Romano dal suo inizio (1551) alla soppressione della Compagnia di Gesù (1773) (Rome: Apud Aedes Universitatis Gregorianae, 1954), 216, 248, 325, 328, 330, 333-34.

27 In Mémoires de Trévoux (June 1702): 114-32. 
only dubious so as not to fall into the certain one."28 Tournemine's statement lent itself to many criticisms, especially since the Jesuit order had strong opponents precisely because such critics so often considered its positions to be probabilistic and lax. These two reviews are nevertheless the only examples closely related to the Chinese rites found in the Jesuit journal of the period in which it was edited by Tournemine.

But, such a relative paucity of coverage does not mean that the Mémoires de Trévoux advanced no precise policy about China and its rites. In fact the great issue China raised for Christianity involved the questioning of chronological biblical canons by stating that the world was immensely ancient. The discussion of chronology led to parallels between sacred history and profane history just as it blurred and obscured the distinction between what was a historical fact and what was a myth, legend or fable. The discussion of chronology further complicated ongoing debates over the morality and religiosity of the Chinese, as well as suggestions that atheist or pagan peoples might be capable of being ethically superior to those who professed Christianity. All these statements were very dangerous for a Catholic orthodoxy then faced with two alternatives: attempt to identify and unify (as far as possible) all other historical narratives with sacred history or condemn them all as imaginary or fanciful while continuing to look for the origin of these falsehoods. Both paths were full of pitfalls because they could lead, either to the dissolution of all particular religions into a single natural religion, or to the interpretation of the biblical story, itself, as imaginary and fanciful. ${ }^{29}$ The Mémoires de Trévoux countered these dangers through its extensive considerations of atheism, and spirited support for the Jesuit method used in China, even if China was never explicitly named. In such manner it is possible to interpret the attention that the Mémoires devoted to atheism and deism.

28 Mémoires de Trévoux (June 1702): 123; for more on the impact of Tournemine on eighteenth-century scholarship, see Burson, "Between Power and Enlightenment," 40-64; and Burson, Rise and Fall of Theological Enlightenment.

29 See Paolo Rossi, I segni del tempo: Storia della Terra e storia delle nazioni da Hooke a Vico (Milan: Feltrinelli, 2003; first edition 1973), 182-83. On this subject, see also Sergio Landucci, I filosofi e i selvaggi 1580-1780 (Rome: Editori Laterza, 1972; repr. Turin: Einaudi, 2014), and Giuseppe Ricuperati, "Comparatismo, storia universale, storia delle civiltà: Il mutamento dei paradigmi dalla 'crisi della coscienza europea' all'Illuminismo," in Le passioni dello storico: Studi in onore di Giuseppe Giarrizzo, ed. Antonio Coco (Catania: Edizioni del Prisma, 1999), 511-80. On China particularly, cf. Sergio Zoli, Europa libertina tra Controriforma e Illuminismo: L'Oriente" dei libertini e le origini dell'illuminismo; Studi e ricerche (Bologna: Cappelli, 1989). 
In 1702, the year in which the works concerning the Chinese rites controversy were reviewed, a kind of synergy was reached with Gottfried Wilhelm Leibniz (1646-1716) whose concept of Confucianism owed much to the writings of the Society of Jesus, and whose strength in fighting "les raisons des Athées" the editors of the Mémoires appreciated. ${ }^{30}$ And again in 1702, just a few years after its publication, the journal reviewed Demonstratio Tripartita Dei adversus Atheos et Gentiles: Christi adversus Judaeos et Paganos; Ecclesiae adversus Haereticos et Schismaticos; Suffragante per omnia Augustino (Tripartite demonstration of God against atheists and gentiles: Christ against the Jews and pagans; the church against heretics and schismatics, supported throughout by St. Augustine) (Cologne, 1700) by the Jesuit Barthélemi Fibus (1643-1706). ${ }^{31} \mathrm{Al}-$ ready in 1696, in Cologne, Fibus had published Via Veritatis et vitae, in unitate fidei salvificae: Per genuinam interpretationem D. Augustini super Epistolam ad Romanos; Perque varias deductiones Theologico-Polemicas, contra Atheos, Paganos, Judaeos, Mahumetanos, Haereticos et Infidelis quoscunque, Novissime ac perspicuè demonstrata (The path of truth and life in the unity of the faith of God's salvation by means of the genuine interpretation of St. Augustine concerning the Epistle to the Romans, through which are demonstrated various polemical theological deductions against atheists, pagans, Jews, Muslims, heretics, and infidels, both old and new). But, in the 1700 publication the Mémoires decided to review, Fibus introduced an important innovation as compared to his previous work. In the 1700 publication, the enemies he intended to rebut were now paired two by two: the atheists with the gentiles, the Jews with the infidels, and finally, the heretics with the schismatics, all arrayed in a sort of circle that proceeded from the denial of God, to the less grievous denial of the truths of the "Holy and Catholic" church, through the intermediate denial of the truths of Jesus Christ. The pagans, both ancient and modern, Fibus associ-

$30 \quad$ Mémoires de Trévoux September 1702): 78-85, here 80. On Leibniz and China, see Fausto Fraisopi, "L'attualità di Matteo Ricci in Leibniz: Tra linguaggio universale e relatività dei riti," in Humanitas: Attualità di Matteo Ricci; Testi, fortuna, interpretazioni, ed. Filippo Mignini (Macerata: Quodlibet, 2011), 251-75; Julia Ching and Willard G. Oxtoby, Moral Enlightenment: Leibniz and Wolff on China (Nettetal: Steyler Verlag, 1992); Donald F. Lach, "Leibniz and China," Journal of the History of Ideas 6, no. 4 (1945): 436-55, and more generally Olivier Roy, Leibniz et la Chine (Paris: J. Vrin, 1972), 63-72 and Franklin Perkins, Leibniz and China: A Commerce of Light (Cambridge: Cambridge University Press, 2004).

31 The work by Fibus work was again published in Cologne, in 1736. Barthélemi Fibus, S.J., was born in Aix-la-Chapelle in 1643, was professor of theology in Cologne for twentyfive years, and died on February 13, 1706. For these biographical details, see Carlos Sommervogel, ed., Bibliothèque de la Compagnie de Jésus (Brussels and Paris: O. Schepens and A. Picard (1890-1932), 3:coll.714-15. 
ated with atheists because they were all unaware of the truth of God, some through ignorance, and some by an explicitly voluntary act.

The Mémoires review of Fibus was merely descriptive, a simple indication of the "principal matters of which the three Demonstrations have spoken."32 This same descriptive mode was used for the Entretiens de la religion contre les Athées, les Déistes, \& tous les autres ennemis de la Foy Catholique par Mr. Michel Levasseur, Prêtre du diocèse de Blois (1705) (Conversations on religion against the atheists, the deists, and all other enemies of the Catholic faith by Mr. Michel Levasseur, priest of the diocese of Blois) when its reviewer referred to the work's fundamental contribution to the doctrine of the non-existence of "true atheists," véritables athées, and remarked that "if peoples can be found who do not know God (a fact which is not uncontested) they are so gross that they have no reflection whatsoever on the Universe, or on the arrangement of creatures or on themselves." 33 This form of atheism was one of the themes fostered, both directly and indirectly, by information coming from distant lands-from missions among the barbarians and the civilized. Such information generated by Jesuit mission found the Mémoires de Trévoux an excellent vessel of dissemination. For instance, the journal regularly reviewed the volumes of the Lettres édifiantes et curieuses in which the Jesuits scattered throughout the world summarized for the Europeans the civilizations they had encountered during their missionary adventures. ${ }^{34}$ Their tales, already rewritten and censored, ${ }^{35}$ were selected by the editors mainly in order to highlight the most daring aspects of the journey, the curiosities of material life, the course of politics, or the facts of exotic customs. The Mémoires acted as a sounding board for the missions that Jesuits carried out throughout the planet, and devoted special attention to the Far East, to those peoples whose morals seemed to conform to Christianity. At the same time, and in the form of current events reportage, the Mémoires informed the reading public about the populations that had most recently become the objects of Jesuit missionary activity, and about people made up of tribal organizations whose existence had raised issues of religious belief and practice. And it was in fact to the Moxos (an indigenous people from Bolivia), and to the no less interesting Canadian populations, that the Mémoires devoted such large excerpts, choosing in such long letters precisely those passages

32 Mémoires de Trévoux (July 1702): 103-8, here 107-8.

33 Mémoires de Trévoux (October 1706): 1729-36, here 1733.

34 Mémoires de Trévoux (February 1703): 219-44; (June 1707): 1023-52; and for a description of Chinese Jews by Giampaolo Gozani (December 1711): 2049-61; (July 1715): 1133-75 and passim.

Pinot, Chine et la formation de l'esprit philosophique, 229-41. 
that illustrated the presence of a mixture of idolatry and atheism, revealing them to have been divided between those who worshipped the sun, the moon, the wind, or some other demon; and those who, on the other hand, lived "without any sentiment of religion" or without "the least remnant of any religious cult." ${ }^{36}$ These last descriptions gathered together all peoples under the umbrella of a negative atheism, that is, those who lacked any element of a willing denial God, but whose atheism resulted from their status as men without reason and not from a voluntary and well-considered choice. Ultimately, even negative atheism was dangerous for European Christianity.

Not coincidentally, Editor Tournemine felt the need to intervene directly on this matter and to denounce the many contradictions contained in the missionaries' and the travellers' documents. In his Réflexions sur l'athéisme attribué à quelques peuples par les premiers missionnaires qui leur ont annoncé l'Evangile (Reflections on atheism attributed to some peoples by the first missionaries who announced the Gospel to them), published in Mémoires de Trévoux in 1717, the Jesuit intended to weaken the meaning of the descriptions (now deemed subversive in Europe) that had represented those populations as atheists by applying, or so he argued, a theological framework that was alien to their original cultural contexts: "Do not look in those savages for a knowledge of God conforming to that of the Theologians, endeavour to unearth the knowledge which nature has given them, and you will not mistake them for Atheists." ${ }^{37}$ Instead, their alleged atheism was in fact a pure idolatry that had originated in the corruption of education and in fables, but certainly not in any kind of primitive atheism, Tournemine wrote, because one is not an atheist when one forgets or doubts God, or when one commits oneself to disbelieving, or to displaying disbelief in God. Tournemine assumed that atheism was born when one was convinced of the non-existence of God, and therefore, atheists did not exist, and in fact never had existed. From time to time there was news of the discovery of atheist people in some part of the world, but their atheism was only the fruit of the soul's corruption, or of interpretative errors on the part of European missionaries and travellers.

Tournemine paid a stubborn attention to the cultures of others in the context of the historical erudition of the early eighteenth century. He was determined to disprove hypothesis that the Chinese chronology was older than the biblical one, and began by comparing the Hebrew texts of the Bible, the

$36 \quad$ For review of volume 12 of the Lettres édifiantes (Paris, 1717), see Mémoires de Trévoux (January 1717): 19-36, here 22.

Mémoires de Trévoux (January 1717): 36 -39, here 38. 
Samaritan edition, and the Septuagint, ${ }^{38}$ thereby endeavoring to preserve the universality of the history of the Old Testament by covering every possible interpretation capable of broadening the biblical chronology and uncovering coincidences (however hidden among prophecies and mysteries) between the Bible and the ancient histories and myths of other ancient peoples encountered. By another path, Tournemine's endeavored once more to reduce the field of action of those who had questioned the unity of the original world and, with it, the universal value of religion.

The problem of the godless (a term used at times for a category that was not always well defined $)^{39}$ also appeared in René-Joseph Tournemine's staunch dedication to the theme of fables through which he led his fight against idolatry and his refutation of other gods and myths. Tournemine became convinced "that natural religion, or rather, the religion that Noah and his children had professed, possessed its own mysteries, prophecies, and ceremonies; and as such, many fables of other ancient peoples were nothing less than those Noahic mysteries and prophecies altered by the fictions with which men had mixed them." $40 \mathrm{On}$ all fronts the Jesuit remained steadfast in maintaining the existence of a long common genealogy of humanity, in both present and ancient times, while elaborating a method for bringing all the ancient fables back to their only consistent Noahic root, in a way that suggested an anthropological unity evidenced in Genesis but now obscured by the supposed dichotomy between believers and infidels.

Tournemine's proposed Project d'un ouvrage sur l'origine des fables (Project of a work on the origin of fables) was aimed at all skeptics who denied or doubted the existence of God's plan, of his universal design, or even his existence. The theme of immense antiquity was not really new in the early eighteenth century, but it was certainly rendered newly appealing and convincing by the knowledge of China. The Jesuits had highlighted the ancient chronology of Chinese history while ironically beginning a systematic and destabilizing cultural undertaking through their new reading of the ancient Confucian texts.

38 Mémoires de Trévoux (March 1703): 452-64; (June 1709): 947-52; (January 1710): 103-21. For a survey of Tournemine's many contributions to the Mémoires de Trévoux, see Sommervogel, ed. Bibliothèque, 8:coll.179-94.

39 See Jan N. Bremmer, "Atheism in Antiquity," in Cambridge Companion of Atheism, 11-26. On the evolution of the term "atheism" in the Western culture of societies controlled by the Inquisition, see Vittorio Frajese, "Ateismo," in Dizionario storico dell'Inquisizione, ed. Adriano Prosperi (Pisa: Edizioni della Normale, 2010), 1:114-18.

40 Mémoires de Trévoux (November-December 1702): 84-111, here 89-90. 
Indeed, since 1697, Father Joachim Bouvet $\left(165^{6-1730}\right)^{41}$ had theorized that the ancient classical texts of China had already contained the main mysteries of the Christian faith hidden beneath their obscure prophecies and wisdom. As Bouvet had confided to Leibniz in 1702, the Jesuits' task was thus to bring these hidden meanings back to light,

since after some two thousand years, they nearly lost all knowledge of the true God, having lost the hieroglyphic meaning of their characters and the comprehension of their ancient books, they were only able to keep a superficial estimate of the doctrine herein contained, that after such a long time it stopped making their spirit feel the sublimity and holiness of truth and of the maxims that constitute its true essence. ${ }^{42}$

Accordingly, in 1704, Tournemine decided to publish one of the many letters between Leibniz and Bouvet. ${ }^{43}$ The text, important for the theory of binary arithmetic, contained references found in Chinese classics to the Christian law in the form of the Jewish tradition, explaining that Japhet, son of Noah, had found refuge in Asia and brought with him the ancient law. Thus, "the philosophers of this Orient celebrate the sovereign being that they have known and they worship at least as clearly as the other philosophers of all the nations, except for the Christians and the Jews." 44

Tournemine further intended to write a book, set within the tradition of the fathers of the church, and designed to uncover analogies between the histories and religion of Greeks and Romans and those of the new populations of the new worlds. ${ }^{45}$ This book would also have taken into due consideration the

41 On Joachim Bouvet, see also Claudia von Collani, P. Joachim Bouvet S.J.: Sein Leben und sein Werk (Nettetal: Steyler Verlag, 1985).

42 Bouvet's letter to Leibniz, November 8, 1702, in Gottfried Wilhelm Leibniz, Allgemeiner, Politischer und Historischer Briefwechsel, vol. 21: April-Dezember 1702 (Berlin:Verlag, 2012), 615-19, here 616. See also Geneviève Javary, "Hou Ji, prince Millet, l'agriculteur divin: interprétation du mythe chinois par le Père Joachim Bouvet, s.j.," in Appréciation par l'Europe de la tradition chinoise à partir du XVII ${ }^{e}$ siècle: Actes du III ${ }^{e}$ colloque international de sinologie; Centre de Recherches interdisciplinaire de Chantilly (CERIC), 11-14 septembre 1980 (Paris: Les Belles Lettres, 1983), 93-106.

43 Mémoires de Trévoux (January 1704): 28-164.

44 Mémoires de Trévoux (January 1704): 159.

45 See also Phiroze Vasunia, "Ethnography," in The Classical Tradition, ed. Anthony Grafton, Glenn M. Most, and Salvatore Settis (Cambridge, MA: The Belknap Press of Harvard University Press, 2010), $335-38$. 
innovations brought about by the study of East Asian languages undertaken by earlier Jesuits. In this proposed work, Tournemine aimed to prove

that what Moses teaches us of the creation of the world, of original sin, of the extreme corruption of man after several centuries, of the universal deluge, of the propagation of the human race by one man and his three sons, [and] of the dispersal of peoples after the deluge [is true] not only because of the divine authority of the writings of Moses; not only because of their antiquity, which far surpasses any historical monuments remaining to us; but also because of the consent of all people. There are few in whom tradition has not conserved these facts, and though they are somewhat altered and mixed with fables, they nonetheless are always recognizable if one would make the least effort to discern them. ${ }^{46}$

Tournemine's cultural operation, and that of the Figurists, was in many respects to vindicate the validity of the doctrine of the consensus gentium, and the primordial antiquity of Christianity, because it had become obvious to every learned reader and writer of the time that the antiquity of the Chinese was not solely the concern of those interested in China only. ${ }^{47}$ In fact, the controversy about China's rites generated other considerations of interest for the intellectuals of the eighteenth century starting with the matter of understanding other cultures, with language, and therefore with what could be inferred from individual words about the religions of other peoples. ${ }^{48}$

Tournemine's project remained only in the form of a draft manuscript, but it was often cited in the Mémoires to mitigate the tone of excessive rationalism characteristic of countless works dedicated to the myths of humanity, and to help find a path between the various interpretations provided by the many scholars and writers, both within and beyond the Society of Jesus, who had

46 Mémoires de Trévoux (November-December 1702): 86.

47 On the Figurists, see Michael Lackner, "Jesuit Figurism," in China and Europe: Images and Influences in Sixteenth to Eighteenth Centuries, ed. Thomas H. C. Lee (Hong Kong: The Chinese University Press, 1991), 129-49.

48 See on this matter the review, in Mémoires de Trévoux (December 1706): 2043-59, of Histoire des Incas rois du Perou de Garcilaso de la Vega, trans. Jean Baudouin (Amsterdam, chez Gerard Kuyper, [1704]) where the dispute on the Inca word "Pachacamac"("âme du monde" according to some, while others maintain there is no Inca word for divinity) was considered analogous to events in China, and to the debate around the Chinese name of God. 
faced this thorny issue. ${ }^{49}$ The theme of fables, moreover, so crucial in ancient and modern paganism, would keep the Mémoires de Trévoux very busy. The Jesuit journal had strongly criticized the 1706 edition of Fontenelle's Histoire des oracles (History of oracles) by suggesting that interpreting the Old Testament as a species of fantastic fairy-tale, arguing that every idea of revealed religion was imposture, and embracing any idea of deism as having been the most common form of natural religion prior to all particular religions assumed by different cultures should be avoided all together. ${ }^{50}$ In 1712, the publication of the Démonstration sur l'existence de Dieu was announced; it would appear anonymously the following year and soon be attributed to Fénelon. Reviewed in March 1713, it dealt with the issue of a "veritable" atheism. ${ }^{51}$ Fénelon's work was an attempt to answer Pierre Bayle (1647-1706), an author the journal reviewed more than once with a tone that would change over time, particularly starting with the Dictionnaire historique et critique. The Mémoires de Trévoux would end up levelling many more personal attacks on Bayle than it would on his theories. ${ }^{52}$ The work was also yet another critique of Nicolas Malebranche (1638-1715) who had already been excoriated in 1708, in the pages the Mémoires devoted to Entretiens d'un philosophe chrétien et d'un philosophe chinois, sur l'existence et la nature de Dieu (Conversations of a Christian philosopher and

49 See for example, the review of Antoine Banier's Explication historique des fables, où l'on découvre leur origine et leur conformité avec l'histoire ancienne, published in 1711, which makes use of Tournemine's unpublished draft, in Mémoires de Trévoux (September 1711),

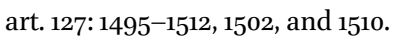

5o The first edition of Fontenelle was published in 1686: see Mémoires de Trévoux (August 1707): 1386-88, and Fontenelle's long reply to the Système de Mr. Van-Dale, sur les auteurs des oracles du paganisme, in addition to the extensive space devoted to the rebuttal to Fontenelle by Jean François Baltus (1667-1743), Mémoires de Trévoux (August 1707): 13891407. The reviewer of volume 9 of the Lettres édifiantes also quoted Baltus in his explanation that India and China constituted proofs of the theory that demons were responsible for the oracles of paganism: see Mémoires de Trévoux (December 1711): 2053; see also Elie Benoit's Réfutation of Toland's work in Mémoires de Trévoux (February 1714): 237-59.

$51 \quad$ Mémoires de Trévoux (November 1712): 2037; Mémoires de Trévoux (March 1713): 459-62.

$5^{2} \quad$ Mémoires de Trévoux (July 1713): 1149-50. But in Mémoires de Trévoux (February 1715): 212-19, there is a mention of the typical qualities of the godless in the Catholic tradition, doubting his honesty and sincerity, and accusing him of dissembling. See also Ribard, "Pratique(s)," 516. On the representation of the atheist, see Michela Catto, "An InterCultural Prism: The Representation of the Belief in the Atheism of the Chinese as a Play of Mirror between the Society of Jesus and Philosophes," in Representations of the Other and Intercultural Experiences in a Global Perspective, ed. Niccolò Guasti (Milan: Mimesis International, 2017), 63-82. 
a Chinese philosopher on the existence and the nature of God). Malebranche was primarily criticized because of his alleged Spinozism, and his foundational link between the Chinese and atheism made "uniquely" on the basis of the notions "that we have of God." ${ }^{33}$ Tournemine's unsigned Préface to the Démonstration would be the object of further reflections until it became a fully independent treatise on the occasion of the second edition (1718) of the CEuvres philosophiques with the title, "Réflexions du père Tournemine jésuite sur l'athéisme, sur la Démonstration de Monseigneur de Cambrai et sur le système de Spinoza, qui ont servi de préface aux deux éditions précédentes de la Démonstration, augmentée de nouveau" (Reflections of the Jesuit Fr. Tournemine on atheism, on the demonstration of His Eminence Cambrai and on the system of Spinoza, which served as a preface to the two previous editions of the demonstration, newly augmented). ${ }^{54}$ Most of it was published yet again in the Mémoires de Trévoux. ${ }^{55}$

The real subject of the Préface, first published anonymously in 1713, was the existence of God and the speculative impossibility of the existence of true atheists. The argument was developed from an essentially philosophical point of view and, as such, was in full harmony with Fénelon's text. But Tournemine took the opportunity to return to some of the topics that had influenced his role as the editor of the Mémoires de Trévoux. As we know, his was a close and thorough critique of Pierre Bayle's best-known thesis concerning the existence of a society of atheists, but Tournemine did not hesitate to point out the inconsistency of the proof based upon accounts of the existence of barbarous populations described as having no knowledge of God; such evidence, Tournemine wrote, derived from "some uncertain reports and [was] contradicted by

53 Mémoires de Trévoux (July 1708): 1134-53: the parallels between atheism and Chinese philosophy, the reviewer writes, may be shared neither by Chinese nor by Christian philosophers, and this was certainly true for the Emperor of China "autant éloigné de l'athéisme, qu'il est sçavant dans la Philosophie de sa Nation" (as far removed from atheism as it is from the philosophy of his nation). For more on Malebranche, see Mémoires de Trévoux (December 1708): 1977-85, followed by Réflexions sur les avis précédents $d u$ R.P. Malebranche (1985-2004), in Mémoires de Trévoux (July 1708): 1137.

54 Fénelon, CEuvres philosophiques (Paris: Florentin Delaune, 1718), 523-59. See also Ribard, "Pratique(s)," 523 .

55 Mémoires de Trévoux (January 1719): 5-54, here 31-32. The first and second editions were in fact very different, as the second consists of two works written at different dates. Clearly, Fénelon's apologetic was designed to convert the libertines by appealing to reason and trusting in philosophy alone. See Henri Gouhier, Fénelon philosophe (Paris: J. Vrin, 1977), 127-31. 
more faithful reports." ${ }^{26}$ For the Jesuit, the members of Bayle's supposed society of atheists comprised men who lacked reason rather than religion, a people "steeped in matter, busy with the perceived," who had never thought of God, or had forgotten him, but whose atheism was certainly not born of reasoning.

China was the most important proof Bayle used to support his theory. Particularly in Continuation des Pensées diverses, écrites à un Docteur de Sorbonne à l'occasion de la Comète qui parut au mois de Décembre 1680 (Continuation of the various thoughts written to a doctor of the Sorbonne, on the occasion of a comet which appeared in the month of December 1680) (1704), and in Réponses aux questions d'un provincial (Reply to questions of a provincial) (1704-6), Bayle had argued the existence of the Chinese's congenital atheism in the form of "a numerous, enlightened sect that openly professes atheism." 57 Bayle's position especially concerned Confucianism: "The most able missionaries of China, some of whom are of your society, maintain, that the greatest part of literati there are Atheists, and that they are idolaters only through dissimulation and hypocrisy." As Bayle wrote in his Dictionnaire historique et critique (1697), quoting Antoine Arnauld (1612-94), "The same missionaries inform us, that these literati do not believe anything to be spiritual, and that the King above, which your Matteo Ricci took for the true God, is nothing but the material Heaven [...]. But others, who have studied these matters with greater care, as your Father Nicolò Longobardi [1559-1654], maintain, that this Philosopher [Confucius] said many fine things about morality and politics; but, as to the

$5^{6} \quad$ Fénelon, Oeuvres philosophiques, c. aiiij ${ }^{\mathrm{r}}$. On the changing relation between atheism and theology, see Alan Charles Kors, "Theology and Atheism in Early Modern France," in The Transmission of Culture in Early Modern Europe, ed. Anthony Grafton and Ann Blair (Philadelphia: University of Pennsylvania, 1990), 238-75.

57 Préface, in Fénelon, Oeuvres philosophiques, [8]. The connection between Chinese atheism and Spinoza dated back to Pierre Bayle's Dictionnaire historique et critique (1697), which stated in the Spinoza entry that although Spinoza was an "atheist of system" and had "adopted a completely new method," his "doctrine has common foundations with many other ancient and modern European and Eastern philosophers' doctrines": Pierre Bayle, Historical and Critical Dictionary, trans. Pierre Des Maizeaux, 5 vols. (London: J. J. and P. Knapton, 1738), 5:199-223. See also Yuen-Ting Lai, "The Linking of Spinoza to Chinese Thought by Bayle and Malebranche," Journal of the History of Philosophy 23, no. 2 (1985): 151-78, and Thijs Weststeijn, "Spinoza Sinicus: An Asian Paragraph in the History of the Radical Enlightenment," Journal of the History of Ideas 68, no. 4 (2007): 537-61. On Bayle and China, see also Simon Kow, China in Early Enlightenment Political Thought (London: Routledge, 2017), 41-78. More generally for the image of China in European Culture, see Basil Guy, The French Image of China before and after Voltaire (Geneva: Institut et Musée Voltaire, 1963). 
true God, and his law, he was as blind as the rest."58 Bayle, who was trained by the Society of Jesus, forcefully posited the dilemma of the existence of a virtuous society of atheists, thereby instilling doubts and uncertainties about the validity of the theories that linked morality to revealed religion.

According to Tournemine, however, such a living and real example of a society of atheists among the Confucian literati was totally false and inconsistent. The Chinese spoke of divinity in "magnificent" terms, "they express[ed] themselves like we do on the creation, the conservation of the universe, on providence: a very peculiar species of atheists indeed,"59 Tournemine mused. The Confucian literati were in error but being wrong was not a denial of God's existence. Even when Father Tournemine addressed materialistic atheism-which he did solely in the case of China-he could not accept that the principle of order and creation, the $L i$, connected the Confucians to the never named Spinoza $\left(163^{2-77)}\right.$. The theoretical system was absurd, once again, but it was not sufficient to accuse the Chinese of atheism.

True atheists did not exist in Europe or in China or anywhere else in the world, albeit the Jesuit Tournemine felt the impellent need to defuse the device of alleged Chinese atheism which then seemed so capable of proselytizing among the unbelievers of Europe. In his view, it was important to speak of the existence of God not in order "to disillusion convinced minds" but "to strengthen vacillating minds." Only by staving off "the darkness that passions spread over a truth that thwarts them," one could force men, those "who want to disbelieve, their reason notwithstanding," to see God. ${ }^{60}$ This was the battle that, during the years in which he was editor of the Mémoires de Trévoux, Tournemine fought while wisely avoiding any direct participation in the Chinese rites controversy, and decisively contributing to the Jesuit cause in China by addressing those themes that explained the existence of a Chinese wisdom originating from the same ancient roots as Christianity. His eyes were on distant peoples, but his concerns grew out of the increasingly strong roots of European unbelief.

In conclusion, Bayle's skepticism concerning the existing link between religion and morals, in addition to the positions of many deist writers associated with the Enlightenment, were the outcome of a longstanding set of debates. But as argued in the preceding, these controversies would hardly have unfolded as they did without the reports on the customs and conventions of

\footnotetext{
$5^{8}$ Bayle, Historical and Critical Dictionary, 4:81, entry "Maldonat."

59 Préface, in Fénelon, Oeuvres philosophiques, [10].

6o Mémoires de Trévoux (March 1713): 459-70, here 46o.
} 
non-European peoples throughout the world that originated from the Society's missions, and from the painstaking intellectual labor that the Jesuits (particularly many of those in France) undertook to interpret the sources produced by the Jesuit missionaries before making them available to the wider European public. 